\title{
Changing approaches to classroom assessment: An empirical study across teacher career stages
}

Andrew Coombs, Christopher DeLuca, Danielle LaPointe-McEwan, \& Agnieszka Chalas

Faculty of Education, Queen's University, Kingston, Canada

Full Citation:

Coombs, A., DeLuca, C., LaPointe-McEwan, D., \& Chalas, A. (2018). Changing approaches to classroom assessment: An empirical study across teacher career stages. Teaching and Teacher Education, 71, 134-144. https://doi.org/10.1016/j.tate.2017.12.010

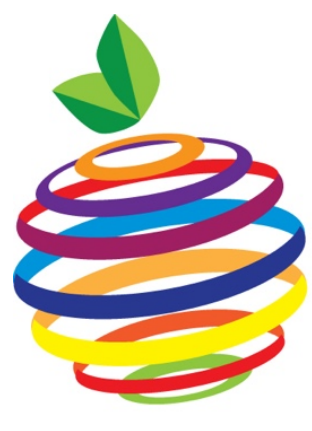

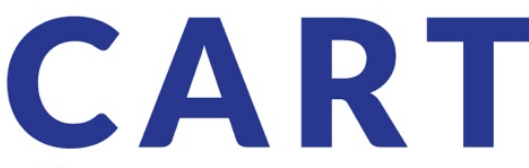

Classroom Assessment Research Team cdeluca.com
Contact:

Christopher DeLuca cdeluca@queensu.ca

@ChrisDeLuca20 


\begin{abstract}
Research indicates that there is considerable variability in teachers' approaches to assessment resulting in different learning cultures for students. The primary purpose of the study is to examine the relationship between teachers' approaches to assessment across a set of dimensions (including their conceptions of assessment purposes, processes, fairness, and measurement theory) and career stage. The results of this paper illustrate nuanced impacts of career stage on teachers' approaches to multiple dimensions of assessment and enable the generation of assessment profiles that provide empirical support for differences in teachers' approaches to assessment both within and between career stages.
\end{abstract}

Keywords: classroom assessment, assessment literacy, approaches to classroom assessment, assessment profiles, career stage, teacher education 


\section{Introduction}

There is no shortage of evidence to suggest that teachers' classroom assessment practices influence student learning and the learning environment. This influence is even more pronounced within the current accountability climate across many schools in North America and elsewhere (Bennett \& Gitomer, 2009; Brookhart, 2011; Herman, 2008, Kauffman, Johnson, Kardos, Liu, \& Peske, 2002). Recent policy developments towards data-informed teaching, assessment for learning, and a surge in large-scale assessments have resulted in a multitude of assessment practices occurring within classrooms, often predicated on fundamentally different orientations towards assessment and measurement (Birenbaum et al., 2015; Black \& Wiliam, 2006; Stobart, 2008). As a result, teachers have variable understandings and approaches to assessment, with students experiencing classroom-learning cultures that value and use assessments in significantly different ways (Shepard, 2000). A teacher's approach to assessment is comprised of both conceptual understandings and practical knowledge related to student assessment within the situated context of their classroom teaching. For example, a classroom culture that values formative assessment tends to rely on a socio-constructivist understanding of learning in which students are actively engaged in monitoring their learning through self-, peer-, and instructorbased feedback with the aim of supporting both academic content learning and learner independence (Assessment Reform Group, 2002; Black \& Wiliam, 2009; Earl, 2012). In contrast, traditional classroom cultures that prioritized summative assessments to benchmark student learning typically used a teacher-centric model of instruction (Bennett, 2011; Shepard, 2000; Wolf, Bixby, Glenn, \& Gardner, 1991).

Previous research on teachers' approaches to assessment has pursued three dominant lines of inquiry. The first line of inquiry, rooted in assessment practice, has explored the 
psychometric and functional aspects of specific classroom assessment strategies to measure student learning (e.g., testing practices, summative assessments, portfolios, self- and peerassessments, technology-based assessment) (e.g., Harrison, 2010; Heritage \& Heritage, 2013; Hoover \& Abrams, 2013; Klenowski, 2010; Ruiz-Primo \& Li, 2013; Salend, 2009). This line of research focused on assessment for learning practices used to guide instruction and enhance student learning. Although aspects of the assessment process (i.e., designing assessments, communication of design and results) and assessment of learning practices are considered, these dimensions of classroom assessment are primarily framed in how they align with assessment for learning practices.

The second line of research has aimed to measure teachers' levels of assessment literacy_educators' knowledge, skills, and dispositions related to assessment (Popham, 2013) using various instruments (e.g., Campbell, Murphy, \& Holt, 2002; Mertler, 2003, 2004; Mertler \& Campbell, 2005; Plake, Impara, \& Fager, 1993; O’Sullivan \& Johnson, 1993). Findings from the majority of these studies indicate that teachers have low levels of assessment literacy, with pre-service teachers particularly limited in their assessment capabilities (Cowan, 2009; MacLellan, 2004; Volante \& Fazio, 2007). Furthermore, results from recent systematic reviews of existing assessment literacy instruments indicate that most of these measures are predicated on dated standards for teacher assessment practices and may not fully represent teachers' current responsibilities and knowledge requirements in assessment (Gotch \& French, 2014).

Recently, teachers' assessment literacy has been reconceptualised as teachers' assessment identity (Adie, 2013; Cowie, Cooper, \& Ussher, 2014; Looney, Cumming, van Der Kleij, \& Harris, 2017; Scarino, 2013; Xu \& Brown, 2016). Building upon previous research into teacher self-efficacy and teacher identity, assessment identity represents a dynamic construct that 
includes not only assessment knowledge and skills but also an affective dimension. This reconceptualization suggests that teacher assessment literacy is closely coupled with personal, social, and contextual aspects of their teaching identity and more than an accumulation of assessment knowledge and skills.

The last line of inquiry has served to understand teachers' perspectives on the value and function of various assessment purposes (e.g., Brown, 2004; Remesal, 2011; Smith, Hill, Cowie, \& Gilmore, 2014; Wolf et al., 1991). For example, Brown and colleagues' (Brown, 2004, 2006; Brown \& Harris, 2009; Brown, Lake, \& Matters, 2011) have worked to identify major conceptualizations of assessment purposes across diverse geographic and teaching contexts. Dominant conceptualizations identified include assessment for the improvement of teaching and learning, assessment for school accountability, assessment for student accountability, and assessment as irrelevant. Moreover, this body of research draws a consistent distinction between various purposes of classroom assessment, ranging from societal/systemic accountability purposes to formative/pedagogical purposes, while acknowledging the influence of systemic educational cultures on teachers' approaches to assessment. Overall, studies on teachers' approaches to assessment consistently demonstrate that teachers conceptualize and value assessment purposes differently and that teachers' classroom practices are driven, in part, by their overarching understandings of the purposes of classroom assessment.

Across these third lines of inquiry, studies have also examined the influence of teachers' career stages on their assessment practices, knowledge, and skills, as well as the value and function of various assessment purposes. Taken together, these studies suggest that more experienced teachers have a greater perceived skill in assessment practices, possess a greater knowledge of assessment theory and classroom practices (Mertler, 2003), place greater value on 
peer assessment activities (Wen, Tsai, \& Chang, 2006), value intrinsic goals, metacognitive selfregulation strategies, and higher-order thinking tasks (Birenbaum \& Rosenau, 2006), and implement a more differentiated approach to issues of fairness in assessment compared to teachers in earlier career stages. Interestingly, studies examining teachers' conceptions of assessment purposes (e.g., Brown, 2004) or self-perception of assessment abilities (e.g., Zhang \& Burry-Stock, 2003) did not identify significant differences according to teachers' career stages. Despite inconsistent influences of career stage on teachers' approaches to assessment, it is important to note that much of the career stage literature focuses on pre-service teachers' assessment literacy and practice, thus precluding a comprehensive understanding of how career stage influences teachers' approaches to assessment as they move through their careers. Additional research that includes both pre- and in-service teachers is needed to further explore the specific relationships between career stage and teachers' approaches to assessment.

This study extends previous research by examining variability in teachers' approaches to assessment across a broad range of career stages based on a set of underlying dimensions. These dimensions include not only teachers' conceptions of assessment purposes, but also their approaches to assessment processes, their understandings of assessment fairness, and their orientations toward measurement theory. Using a cohort sampling design, our analysis of data from 727 pre- and in-service teachers who completed the Approaches to Classroom Assessment Inventory (ACAI) aimed to identify patterns in teachers' approaches to classroom assessment. We purposefully use the term, approaches to assessment, rather than assessment literacy, to signal not only teachers' assessment practices but also their underpinning theoretical orientations to and philosophies of assessment. Hence, we view a teacher's approach to assessment as comprising both conceptual understandings and practical knowledge related to student 
assessment within the situated context of their classroom teaching. This study was guided by the following two research questions:

(1) What are teachers' approaches to classroom assessment at various career stages?

(2) Are there significant differences in teachers' approaches to classroom assessment across career stages?

\section{Variability in Teachers' Approaches to Assessment Across Career Stages}

Research on the influence of career stage on teachers' approaches to specific assessment practices, learning orientations, or assessment beliefs have identified inconsistent findings: some studies have identified a strong influence of career stage on discrete components of assessment literacy (e.g., Birenbaum \& Rosenau, 2006; Mertler, 2003; Wen, Tsai, \& Chang, 2006) while others have not (e.g., Brown, 2004; Zhang \& Burry-Stock, 2003). Using a large-scale survey, Plake et al. (1993) examined in-service teachers' assessment knowledge, concluding their low scores on the instrument indicated a lack of preparedness for classroom assessment practices. Using the same survey instrument, Campbell, Murphy, and Holt (2002), determined pre-service teachers' assessment knowledge was lower than that of the in-service teacher population in Plake et al. (1993). Mertler (2003) compared pre-service and in-service teachers' assessment knowledge with a slightly modified instrument to the previous studies, obtaining similar results to those previously discussed. Mertler and Campbell (2004) created an instrument based upon assessment scenarios, albeit still with a set of correct and incorrect responses, to examine the assessment knowledge of pre-service teachers. Despite the contextualized nature of the instrument, pre-service teachers scored similarly to previous studies. Recently, Volante and Fazio (2007) identified variable levels of pre-service teachers' self-perceived levels of assessment literacy across the multiple aspects of classroom assessment (i.e., higher confidence 
in summative assessment practices, lower confidence in formative assessment practices).

Across many educational contexts (e.g., Canada, United Kingdom, United States) the rise of the accountability paradigm has placed pressures on classroom teachers, specifically through the growing prominence of academic standards and assessment of student achievement (Nichols \& Harris, 2016; Stobart, 2008). Heightened accountability pressures may impact upon classroom teachers' assessment practices by discouraging assessment practices that promote student learning (e.g., formative assessment practices; Black \& Wiliam, 2009) in favour of those that measure student learning (e.g., summative assessment practices; Stobart, 2008). Research has also shown that accountability pressures may not be similarly experience by teachers based upon their career stage (Kauffman et al., 2002).

While evidence from previous research suggests that career stage does have some influence on teachers' approaches to assessment, the majority of studies have focused on preservice teachers, with limited comparisons having been made to in-service teachers. Moreover, previous career stage research has typically focused on teachers' assessment knowledge as a proxy for their approaches to classroom assessment, however recent research points to the need to understand teachers' assessment literacy across multiple dimensions (i.e., assessment purposes, processes, fairness, and theory). Additional studies that further distribute and compare teachers across a broader range of career stages and across multiple assessment literacy dimensions might contribute a more nuanced understanding of how teachers change their approaches to assessment throughout their professional careers.

\section{Factors Contributing to Variability}

The previously reviewed literature demonstrated empirical trends related to career stage and teachers' approaches to assessment. In this section, we examine literature that explains why 
career stage might contribute to variability in classroom assessment practices. Specifically, we identified four dominant factors that contribute to variability in teachers' approaches to assessment and shape teachers' changing approaches across their careers. First, over the past century, substantially different notions of classroom assessment have emerged and periodically supplanted the dominant paradigm of teaching and learning. As recognized by Shepard (2000), classroom assessment has evolved from a behaviouristic model to a constructivist, learnercentered model. In the current accountability paradigm, learner-centered classroom assessment aligns with data-driven teaching mandates and supports testing- and assessment-based learning cultures at multiple levels within school systems (Stobart, 2008). Within this paradigm, teachers have been repeatedly called to enhance their assessment literacy in order to implement researchbased policies emphasizing the integration of assessment for, of, and as learning throughout classroom instruction (Stiggins, 1991, 2005; Popham, 2009). However, research has repeatedly shown that some teachers struggle to keep-pace with this changing assessment landscape and continue to rely on traditional or 'once innovative' assessment practices (Bennett, 2011; MacLellan, 2004). Hence, in-service teachers may rely on previous conceptions and practices of assessment, thereby limiting the consistency of approaches to assessment exhibited in classrooms over time.

Second, the concept of 'assessment literacy' has evolved to represent a complex notion in which assessment is closely linked to and influenced by teaching context, teacher beliefs and knowledge, and students' learning needs. While initial definitions suggested that teacher assessment literacy involved the knowledge and skills required to design, administer, score, and use assessment to support and measure student learning, researchers now recognize that teachers' knowledge, skills, and practices of assessment are shaped by several factors. Tierney (2006) 
identified six factors that shaped teachers' approaches to assessment including professional development, teacher beliefs, educational policy (present and former), evaluative inquiry, largescale assessments, and educational research. Across these factors, teachers are often required to negotiate differing, sometimes contradictory, messages about the purpose and process of classroom assessment. Furthermore, teachers value evidence from these various factors differently, leading to a diversity of assessment approaches (Tierney, 2006). These trends indicate teachers' exposure to significant changes in assessment theory, policy, and practice throughout the length of their careers. Coupled with each teacher's unique classroom practice and experiences, variation in approaches to assessment between in-service teachers appears inevitable.

Given the multitude of factors shaping teachers' assessment practices and their varying abilities to negotiate assessment priorities in relation to diverse curricular, pedagogical, and cultural teaching contexts, Willis, Adie, and Klenowski (2013) presented a more contemporary definition of assessment literacy rooted in a sociocultural perspective:

Assessment literacy is a dynamic context-dependent social practice that involves teachers articulating and negotiating classroom and cultural knowledges with one another and with learners, in the initiation, development and practice of assessment to achieve the learning goals of students. (p. 242)

This sociocultural definition of assessment literacy suggests that teachers will, by virtue of their context, experience, background, and other factors, employ varied assessment practices in their teaching leading to diverse approaches to assessment in schools. Accordingly, current understandings of assessment literacy provide a conceptual grounding for variability of 
assessment practices across not only career stage (i.e., experience and background) but also teaching context.

Third, we assert that teachers maintain varying understandings and approaches to assessment because assessment has historically been a neglected area of study within initial teacher education programs. Research indicates that pre-service programs throughout North America typically have minimal requirements related to explicit assessment courses with graduates generally demonstrating low levels of assessment literacy (MacLellan, 2004; Stiggins, 1991; Volante \& Fazio, 2007). Moreover, Taras (2007) suggested that the structure of preservice and other higher education programs deter the effective integration of feedback-driven assessment practices and, in contrast, employ a dominantly summative assessment culture for teaching and learning. As a result, teachers are not necessarily learning about nor experiencing effective and contemporary approaches to assessment within their initial teacher education programs. Once in their professional teaching positions, teachers tend to rely either on their previous experiences of assessment (which are dominantly summative) or adapt to the culture of assessment within their school environments (Mertler, 2003, 2004; Popham, 2013; Stobart, 2008). As a result, teachers employ diverse approaches to classroom assessment predicated on variable foundations of assessment knowledge and skills; yet, there is little empirical data on the degree or nature of this variability across teachers.

Finally, we assert that teachers' experiences within pre-service education programs and as in-service teachers will influence their approach to assessment. Research indicates that teachers develop conceptions of assessment throughout their experiences as teacher candidates (Bachor \& Baer, 2001; Graham, 2005; Volante \& Fazio, 2007) and as in-service teachers (Newmann, Secada, \& Wehlage, 1995). During a teacher education program, teacher candidates 
are exposed explicitly and implicitly to different conceptions of assessment through courses (not just explicit assessment courses), instructor pedagogy, and practicum experiences. Research into how teacher candidates' conceptions of assessment develop across different teacher education programs is limited.

Teacher education programs are often viewed as an early stage in a career-long process of professional growth and development for teachers (Gambhir, Broads, Evans, \& Gaskell, 2008). Research indicates that the effectiveness of in-service professional learning opportunities can vary depending upon both the culture of the school and the structured roles in-service teachers have (Bruce, Esmonde, Ross, Dookie, \& Beatty, 2010). Developing an understanding of how teachers' conceptions of assessment evolve and shift during pre-service education and as an inservice teacher will provide an empirical foundation for targeted assessment education and future research.

\section{Methods}

A survey method was used to analyze teachers' approaches to assessment through a cohort sampling design. In total, 727 teachers completed the Approaches to Classroom Assessment Inventory (ACAI), representing four distinct career stages: (a) initial pre-service teacher (start of teacher education program), (b) beginning in-service teacher (post-teacher education program), (c) early in-service teacher (in-service teacher with five years or less years of experience), and (d) established in-service teacher (in-service teacher with greater than 5 years of experience).

\section{Sample}

Participants were recruited through electronic survey distribution to teacher professional groups and teacher education programs. The overall sample consisted of 863 Canadian and U.S. 
teachers who completed the ACAI over a one-year period (2016-17). All participants were sorted by career stages (e.g., early in-service teachers) and randomly selected for inclusion in this study to ensure similar samples sizes for each career stage. No other criteria (e.g., demographic grouping) were used in the random selection process. Listwise deletion was used to remove missing data, resulting in a final sample of 727. Participants were divided by career stage with $27.2 \%$ at the start of their teacher education program (i.e., initial pre-service teachers), $23.8 \%$ beginning their teacher careers (i.e., post-teacher education program with 0 years of teaching experience), $22.9 \%$ with five or less years of teaching experience (i.e., early in-service teachers), and $26.1 \%$ with greater than five years of classroom teaching experience (i.e., established inservice teachers). Participants included $83.1 \%$ females and $16.9 \%$ males, with similar gender frequencies within each career stage. Across the entire sample age was fairly evenly distributed (35.0\% between 20 and 25 years of age, $35.0 \%$ between 26 and 35 years of age, and $30.0 \%$ over the age of 36). However, age was not evenly distributed between career stages due to a strong relationship between increasing age and later career stages. Participants were also divided by their formal and explicit training at the pre-service level in the area of assessment (i.e., assessment education). Of the sample, 59.1\% reported not receiving any formal training in assessment, $15.0 \%$ completed a single module in assessment (i.e., less than 12 hours), $18.8 \%$ completed a half-year course in assessment (i.e., term course), and 7.1\% completed a full-year course in assessment. Levels of assessment education shifted between career stages. All beginning pre-service teachers reported not receiving any formal training in assessment while the majority $(82 \%)$ of beginning in-service teachers reported completing either a half-year course or module in assessment. Early in-service teacher reported levels of assessment education were more evenly distributed, with a half-course in assessment reported most frequent $(40.5 \%)$. 
Similarly, established in-service teachers reported evenly distributed levels of assessment education, with no formal assessment education most frequent (41.7\%). In addition, participants may have received additional training in assessment through non-assessment specific courses, however these data were not obtained. See Table 1 for complete demographic results.

\section{Instrument}

An adapted version of the ACAI was used in this research. The ACAI was developed based on our previous research in which we analyzed 15 contemporary assessment standards (i.e., 1990-present) from five geographic regions (US, Canada, UK, Europe, Australia, and New Zealand). From this analysis, we developed a set of themes to demarcate the construct of assessment literacy, and which aligned with the most recently published Classroom Assessment Standards from the Joint Committee for Standards on Educational Evaluation (Joint Committee for the Standards of Educational Evaluation, 2015). The following assessment literacy themes were integrated into the ACAI: (a) Assessment Purposes, (b) Assessment Processes, (c) Assessment Fairness, and (d) Measurement Theory. Each theme had associated with it a set of three priority areas. For example, the three priorities associated with the assessment literacy theme of assessment purpose were: assessment of learning, assessment for learning, and assessment as learning. See Table 2 for complete list of assessment literacy theme with definitions of associated priority areas.

Scenario-based items were created for the ACAI that addressed the four assessment literacy themes. An expert-panel method was used to ensure the construct validity of the instrument followed by a pilot testing process. In total, 20 North American educational assessment experts followed an alignment methodology (Webb, 1997, 1999, 2005) to provide feedback on the scenario items. Each expert rated (on a five-point scale) the items based on their 
alignment to the table of specifications and the related assessment literacy theme/priority. Based on expert feedback the scenarios were revised and amended until all items met the validation criteria (i.e., average alignment rating of 4 or more). After the alignment process, the ACAI scenarios were pilot tested with practicing teachers. The ACAI version used in this study included 20 items equally distributed across five classroom assessment scenarios with a second part that included a short collection of demographic data.

The five scenarios represented contemporary assessment dilemmas faced by teachers (see Table 3 for scenario example). Each scenario was followed by four multiple-choice questions related to a different assessment literacy theme: (a) Assessment Purposes, (b) Assessment Processes, (c) Assessment Fairness, and (d) Measurement Theory. Responses for each question reflected teachers' priorities within each of the four assessment literacy themes (Table 2). For each scenario-based question, participants selected among three response options that best aligned to their priority in responding to the scenario.

\section{Data Analysis}

Across scenarios, descriptive (mode) statistics were calculated to determine each participant's approach to assessment in relation to each of the four themes. For the assessment scenarios, frequencies for each approach to assessment across four assessment themes were calculated (Table 4). If two approaches were supported equally, a hybrid variable consisting of the two approaches was assigned. For example, a participant that supported an assessment for learning approach twice and an assessment as learning approach twice, would be assigned the hybrid variable assessment for learning \& assessment as learning. Each participant could be assigned one of six possible approaches to assessment within each Assessment Theme (i.e., three approaches and three hybrid approaches). 
Using a 4 x 6 contingency table (cross tables), Pearson's chi-square tests of independence (chi-square test) were used to determine if there were any significant associations between approaches to assessment across career stage (Table 4). Career stage included four categories: initial pre-service teachers, beginning in-service teachers, early in-service teachers, and established in-service teachers. Each table captured the frequency of each of the six possible approaches to assessment for a particular assessment theme across the four career stages. If the chi-square test indicated a significant association within the contingency table, a post-hoc analysis using a z-test of column proportions with Bonferonni adjustments to significance level $(\alpha=0.05)$ was employed to identify significant differences between career stages within an Assessment Theme. If the contingency table contained one or more cells with a lower than expected count, approaches that contained these cells were removed. The analysis was then rerun with the remaining approaches.

Participants' approaches to assessment across the four assessment themes were then used to create assessment profiles. An assessment profile was created from a unique combination of the six possible approaches across four assessment themes, to show common relationships between themes. Within each career stage, the top five most frequent profiles were determined and described based on participants' response patterns. While these profiles solely represent descriptive associations between assessment themes, they do provide an initial basis for understanding the degree of variability in teachers' approaches to assessment.

\section{Results}

\section{Descriptive Statistics}

Table 4 provides overall descriptive statistics for teachers' approaches to assessment across the four career stages. Within the theme of Assessment Purpose, the most commonly 
supported approaches were assessment for learning (AfL; 44.8\%), assessment as learning (AaL; $23.0 \%$ ), and the hybrid approach of assessment for learning \& assessment as learning (13.6\%). Of the least valued approaches, all entailed assessment of learning (AoL; i.e., AoL \& AfL 3.7\%; $A o L$ 6.1\%; and $A o L \& A a L$ 8.8\%). Within the theme of Assessment Processes, the most commonly supported approaches were communication (35.8\%), design (35.1\%) and design \& communication (19.8\%) while the least valued approaches involved use and scoring (i.e., use/scoring 1.4\%; use/scoring \& communication 3.7\%; and design \& use/scoring 4.3\%). Within Assessment Fairness, the most commonly supported approaches were a differentiated approach (48.7\%), an equitable approach (26.8\%), and equitable \& differentiated hybrid approach (11.0\%). Standard approaches were least valued (i.e., standard \& differentiated 3.6\%; standard 4.4\%; and standard \& equitable 4.5\%). Within the theme of Measurement Theory, the most commonly supported approaches were a balanced approach (48.4\%), a validity approach (18.0\%), and a balanced \& validity hybrid approach (14.4\%). The least valued approaches included reliability (i.e., reliability \& validity $4.8 \%$; reliability $5.5 \%$; and reliability \& balanced $8.8 \%)$.

\section{Inferential Statistics}

In order to determine if there were significant associations between career stage and approaches to assessment within each of the four themes (i.e., Assessment Purpose, Assessment Processes, Assessment Fairness, and Measurement Theory), chi-square tests were conducted (See Table 4). The chi-square test showed a significant relationship between career stage and approaches to Assessment Purpose $\left(\mathrm{X}^{2}[15, \mathrm{~N}=727]=36.020, \mathrm{p}=0.002\right)$. Specifically, initial pre-service teachers (3.0\%) were statistically less likely to support an assessment of learning approach than early in-service teachers (10.2\%). This finding might reflect early teachers' 
prioritization of new professional responsibilities that entail evaluating and reporting on student achievement as compared to teachers at the end of their pre-service programs. Beginning inservice teachers $(20.2 \%)$ were statistically more likely to support the hybrid approach of assessment for learning \& assessment as learning than established in-service teachers (7.4\%). It is possible that teachers who had recently completed their pre-service education programs were attempting to simultaneously prioritize the multiple assessment purposes that are commonly emphasized within contemporary assessment education.

Initially, a chi-square test was not performed to examine the relationship between career stage and all approaches to Assessment Processes as all approaches did not meet the minimum expected cell count. Consequently, three approaches (use/scoring, design \& use/scoring, and use/scoring \& communication) were removed and the chi-square test was re-run. The relationship between the remaining variables was not significant $\left(X^{2}[15, N=727]=22.426, p=\right.$ 0.097). These findings indicate that teachers in our sample did not prioritize assessment design, use, scoring, and communication differently regardless of career stages.

A chi-square test identified a significant relationship between Assessment Fairness and career stage $\left(\mathrm{X}^{2}[15, \mathrm{~N}=727]=33.991, \mathrm{p}=0.003\right)$. Initial pre-service participants $(21.1 \%)$ were statistically less likely to support an equitable approach to Assessment Fairness than beginning in-service participants (34.7\%). This suggests that pre-service teacher education programs may help teachers develop more equitable approaches to classroom assessment. In addition, early inservice teachers (7.2\%) were more likely to support the hybrid standard \& differentiated approach compared to established in-service teachers (1.1\%). It is possible that teachers in the early stages of their careers are navigating inherent tensions between assessing all students in the 
same way and assessing each student differently based on individual needs, whereas established teachers have resolved this tension through years of classroom experience.

A chi-square test identified a significant relationship between career stage and teachers' approach to Measurement Theory $\left(\mathrm{X}^{2}[15, \mathrm{~N}=727]=28.023, \mathrm{p}=0.021\right)$. Initial pre-service teachers (12.1\%) were less likely to support a validity approach than established in-service teachers $(24.2 \%)$. Initial pre-service teachers $(57.1 \%)$ were also more likely to support a balanced approach than early in-service teachers (39.2\%). These findings suggest that teachers with classroom experience, as compared to teachers at the start or end of their pre-service programs, have experienced the complexities associated with reliability and validity in daily practice and have developed personal approaches that address practical considerations associated with measurement theory.

Overall, these results illustrate nuanced impacts of career stage on teachers' approaches to multiple dimensions of assessment. While trends across career stages were not consistent for each assessment literacy theme among teachers in our sample, these results support the need for continued investigation into the influence of career stage on teachers' approaches to assessment purposes, processes, fairness, and measurement theory.

\section{Profile Analysis}

Finally, we analyzed the data for combinations of assessment approaches across themes to determine teachers' assessment profiles by career stage. For each career stage, we discuss the number of unique profiles (i.e., combinations of approaches across each of the four themes in which there was only one participant) and the most common (i.e., top five) profiles (see Table 5) to demonstrate the dominant approaches to assessment within each group of teachers. 
Within the initial pre-service population $(\mathrm{n}=198), 113$ unique profiles were identified with the most common five profiles accounting for $22.1 \%$ of the initial pre-service population. Across the top five profiles, initial pre-service teachers tended to prioritize an assessment for learning approach to Assessment Purpose, a communication approach to Assessment Process, a differentiated approach to Assessment Fairness, and a balanced approach to Measurement Theory. Teachers at this career stage did not prioritize an assessment of learning approach to Assessment Purpose, a use/scoring approach to Assessment Process, a standard approach to Assessment Fairness, and a reliability or validity approach to Measurement Theory.

Within the beginning in-service population $(n=173), 111$ unique profiles were identified with the most common five profiles accounting for $13.5 \%$ of the late pre-service population. These teachers most commonly prioritized an assessment for learning approach to Assessment Purpose, a design approach to Assessment Process, a differentiated approach to Assessment Fairness, and a balanced approach to Measurement Theory. Like the initial pre-service teacher population, these teachers did not place as much importance on an assessment of learning approach to Assessment Purpose, a use/scoring approach to Assessment Process, a standard approach to Assessment Fairness, and reliability or validity approaches to Measurement Theory. Within the early in-service population $(n=166), 112$ unique profiles were identified with the most common profiles accounting for $13.0 \%$ of the early in-service population. Similarly, to the initial pre-service teacher group, the most common profiles involved an assessment for learning approach to Assessment Purpose, a communication approach to Assessment Process, a differentiated approach to Assessment Fairness, and a balanced approach to Measurement Theory. As with initial pre-service and beginning in-service teachers, early in-service teachers did not prioritize an assessment of learning approach to Assessment Purpose nor a use/scoring 
approach to Assessment Process. Unlike pre-service and beginning in-service teachers, early inservice teachers did not emphasize standard and equitable approaches to Assessment Fairness and some identified the importance of a validity approach to Measurement Theory.

Within the established in-service teacher population $(n=190), 107$ unique profiles were identified with the most common profiles accounting for $19.1 \%$ of this group. Established inservice teachers most commonly prioritized an assessment for learning approach to Assessment Purpose, a communication approach to Assessment Process, a differentiated approach to Assessment Fairness, and a balanced approach to Measurement Theory. As with teachers in the initial pre-service and beginning in-service groups, established in-service teachers did not emphasize an assessment of learning approach to Assessment Purpose, a use/scoring approach to Assessment Process, a standard approach to Assessment Fairness, and reliability or validity approach to Measurement Theory.

\section{Discussion}

This research aimed to explore variability in teachers' approaches to classroom assessment across four themes (i.e., Assessment Purposes, Assessment Processes, Assessment Fairness, and Measurement Theory) with respect to different career stages (i.e., initial pre-service teacher, beginning in-service, early in-service, established in-service teacher). Findings from our study suggest that slight but significant differences are evident in teachers' approaches to assessment across career stage, with particular changes in early career teachers' prioritization of Assessment Purposes and Assessment Fairness. Our study also suggests variability in teachers' overall assessment profiles (i.e., combinations of the four assessment themes) with areas of strong priority within each theme across career stage. These key findings hold important implications for understanding: (a) variability in teachers' approaches to assessment, (b) the 
influence of classroom experience on teachers' assessment practices, and (c) the influence of preservice education and professional learning experiences on teachers' approaches to assessment.

\section{Variability in Approaches to Assessment}

While previous research has focused on teachers' knowledge (e.g., Mertler, 2003; Mertler \& Campbell, 2005; Plake et al., 1993), conceptions of assessment purposes (e.g., Brown, 2004; Brown, 2006), or self-perceived assessment literacy (e.g., Volante \& Fazio, 2007), results from this study describe a more complex understanding of teachers' variable approaches to classroom assessment. When examining teachers' priorities within discrete themes (i.e., Assessment Purpose, Assessment Process, Assessment Fairness, Measurement Theory), there appears to be a high degree of consistency. Specifically, a near majority of teachers selected an assessment for learning approach to Assessment Purpose, a differentiated approach to Assessment Fairness, and a balanced approach to Measurement Theory. However, when looking at varying combinations of approaches across the four themes (i.e., profiles), responses indicated a wide variety of unique profiles. In total, there were 443 profiles in our data set, distributed fairly equally across the four career stages. For instance, there were 113 unique assessment profiles among 198 initial preservice teacher participants and 107 unique profiles among 190 established in-service teacher participants. These results suggest that variability in teachers' approaches to assessment comes from the combination of priorities across the four assessment literacy themes.

The variability across assessment themes implies that teachers may operationalize the same approach in different ways. For instance, while two teachers might both have strong priorities towards assessment for learning, the remaining dimensions of their assessment profiles might differ and mediate how assessment for learning is conceptualized and implemented within each classroom. Specifically, assessment for learning would look different in a classroom when 
paired with a differentiated approach to Assessment Fairness and a validity orientation to Measurement Theory than when paired with an equitable or standard approach and a reliability orientation. This study extends previous work (e.g., Brown, 2004; Volante \& Fazio, 2007) by including dimensions of assessment beyond purpose (i.e., for, as, of). Generating a greater understanding of the complexity of teachers' assessment profiles appears critical to understanding the ways assessment intentions are interpreted and implemented in classrooms. Hence, the approach and findings of this research provide empirical evidence of the complexity of teachers' assessment profiles and the variability across teachers within and between career stage groupings.

Practically, these results provide an important basis for supporting teacher professional learning across career stages. Most notably, our findings suggest that pre- and in-service teacher professional learning opportunities need to acknowledge the variability in teachers' approaches to assessment within and between career stages. Specifically, while there may be certain assessment policies and practices that all teachers must learn about as they progress through their careers, professional learning opportunities should also allow teachers to explore areas of interest in assessment that reflect their current priorities and unique approaches. Teacher educators in pre-service programs and/or school districts might consider offering core assessment content that all teachers are required learn at various points over time, while concurrently offering personalized extensions to this core content through collaborative inquiries in assessment. These collaborative inquires would allow teachers to extend their foundational knowledge in assessment and explore nuanced areas of interest with like-minded colleagues. Additionally, it could be valuable to provide pre- or in-service teachers with opportunities to share these personalized learning experiences across collaborative inquiry groups, helping to promote 
professional understanding of different approaches to assessment among educators and foster greater insight into how assessment approaches impact instructional practice and students' learning.

\section{Influence of Classroom Experience}

Previous research has confirmed the influence of classroom experience on teachers' assessment practices primarily through comparisons of pre-service and in-service teachers (e.g., Kauffman et al., 2002; Mertler, 2003). Our study extends this work by demonstrating the nuanced impact of career stage on teachers' approaches to multiple dimensions of assessment. While trends across career stages were not consistent for each assessment literacy theme among teachers in our sample, it is important to note that half of the significant differences detected between the approaches to assessment involved teachers within the first five years of classroom teaching (i.e., early in-service teachers). This career stage had slight but statistically significant increase in support for an assessment of learning approach, an increase in support for a standard $\&$ differentiated approach, and a decrease in a balanced approach to Measurement Theory when compared to other career stages. We hypothesize that these findings suggest that early in-service teachers are responding to the high accountability climate evident across many schools in North America as indicated by Kauffman et al. (2002). Interestingly, previous studies that did not detect a significant influence of career stages on teachers' approaches to assessment were conducted within North America (Brown, 2004; Zhang \& Burry-Stock, 2003). While these teachers might complete their pre-service programs with more formative and differentiated views towards teaching, learning, and assessment, upon entry into the profession they appear to shift towards more standardized and summative assessment approaches. Once teachers establish themselves as professionals and learn to mediate external and internal accountability demands, it 
appears, based on our data and aligned with previous research (Wen Tsai, \& Chang, 2006), that teachers begin to re-prioritize more formative and differentiated approaches to assessment (i.e., after five years). This nuanced understanding is of particular importance as expectations for teachers' assessment literacy are often front-loaded in their career without consideration for development over time through authentic classroom experience.

Furthermore, the emergence of different priorities over a teacher's career provides additional evidence that assessment literacy is a socially-contextual and temporally-dependent construct. In respond to different career context, teachers exercise different conceptions and practices of assessment. Pushing this further, and in concert with current understandings of assessment identity (Adie, 2013; Cowie, Cooper, \& Ussher, 2014; Looney, Cumming, van Der Kleij, \& Harris, 2017; Scarino, 2013; Xu \& Brown, 2016), there may be value in unpacking teachers' changing approaches to assessment alongside broader professional identity shifts over their career. Doing so would firmly ground assessment literacy as both a learned and contextually-dependant professional disposition that is connected to their broader growth and development as an educator.

\section{Influence of Pre-Service Teacher Education}

A significant body of research has indicated that pre-service education programs influence teachers' knowledge and skills in assessment (Bachor \& Baer, 2001; Graham, 2005; Volante \& Fazio, 2007). Our study suggests that pre-service teacher education has the most significant impact on teachers' approaches to issues of fairness in assessment and, in particular, the equitable treatment of students within classroom assessment. While comparisons between teachers at the beginning and end of their pre-service programs revealed slight changes in their approaches across priorities within each assessment theme, changes in their approaches to 
assessment purposes, processes, and measurement theory were not significant for our sample. Taken together, these findings extend previous research by demonstrating that pre-service education, beyond building assessment knowledge and skills, contributes to shifting teachers' orientations toward more equitable approaches to classroom assessment.

\section{Limitations}

Despite the observed significance, our study had several limitations. First, our study used a cohort sampling design of teachers at various career stages, not a longitudinal study following the same group of teachers over time. Therefore, the significant differences between approaches to assessment across career stages could be attributed to various factors including teachers' different educational experiences as students themselves and their different teacher preparatory experiences given the variability in age and career stage within this sample population. Secondly, our survey relied on self-report data. While scenario-based responses were used to mitigate some critique against self-report instruments following Mertler and Campbell's (2005) study, our results are not based on observed teacher practices but on their reported responses to written classroom scenarios. Lastly, the ACAI is a relatively new assessment literacy inventory. Consequently, this study represents another step towards using the ACAI to examine teachers' approaches to assessment; continued research across contexts is required to provide additional validity evidence for the inventory.

\section{Future Directions}

This study has implications for in-service teachers, teacher education, and assessment researchers. Without an awareness of the multidimensional nature of their classroom assessment practices, teachers will struggle to integrate assessment practices that align with their knowledge, experience, and learning environment. Educators within pre-service teacher education programs 
or in-service professional development programs must acknowledge this variability so that meaningful and impactful support for teachers' conceptual understandings and practical knowledge related to classroom assessment can be developed and employed. Assessment researchers must also address this variability by acknowledging the limitations of studying teachers' support for discrete assessment practices, skills, or knowledge; instead framing their studies within a multidimensional model of teachers' assessment literacy.

There is a growing body of scholarship, including this study that suggests assessment literacy is far more than the learning of knowledge and skills in assessment. Rather it is a complex socio-cultural professional disposition tied to teacher identity and other aspects of classroom practice (Adie, 2013; Cowie, Cooper, \& Ussher, 2014; Looney, Cumming, van Der Kleij, \& Harris, 2017; Scarino, 2013; Xu \& Brown, 2016). Accordingly, future research should continue to empirically examine the socially-, contextually-, and temporally situated nature of assessment literacy as fodder for responsive assessment education, whether at pre-service or inservice levels. Gaining a more nuanced understanding of the relationship between teachers' assessment identity and their broader approaches to teaching, learning, and curriculum, as well as the catalytic professional learning experiences that stimulate their professional growth and development will provide fertile ground for enhancing and supporting assessment in schools. Concerted efforts among in-service teachers, teacher educators, and assessment researchers have the potential to move the field toward understanding and implementing approaches to classroom assessment across career stages that simultaneously reflect individual teacher priorities and socio-cultural contexts while allowing them to continue addressing their professional responsibilities within educational systems. 


\section{References}

Adie, L. (2013). The development of teacher assessment identity through participation in online moderation. Assessment in Education: Principles, Policy \& Practice, 20(1), 91-106.

Assessment Reform Group. (2002). Assessment for learning: 10 principles. University of Cambridge, UK: Author.

Bachor, D. G., \& Baer, M. R. (2001). An examination of preservice teachers' simulated classroom assessment practices. The Alberta Journal of Educational Research, 47(3), 244-258.

Bennett, R. E. (2011). Formative assessment: A critical review. Assessment in Education: Principles, Policy \& Practice, 18(1), 5-25.

Bennett, R. E., \& Gitomer, D. H. (2009). Transforming K-12 assessment: Integrating accountability, testing, formative assessment and professional support. In C. Wyatt-Smith \& J. J. Cumming (Eds.), Educational assessment in the 21st century: Connecting theory and practice (pp. 4361). Dordrecht, NY: Springer.

Birenbaum, M., DeLuca, C., Earl, L., Heritage, M., Klenowski, V., Looney, A., Smith, K., Timperley, H., Volante, L., \& Wyatt-Smith, C. (2015). International trends in the implementation of assessment: Implications for policy and practice. Policy Futures in Education, 13(1), 117-140.

Birenbaum, M., \& Rosenau, S. (2006). Assessment preferences, learning orientations, and learning strategies of pre-service and in-service teachers. Journal of Education for Teaching, 32(2), 213-255.

Black, P., \& Wiliam, D. (2006). Developing a theory of formative assessment. In J. Gardner (Ed.), Assessment and Learning (pp. 81-100). Los Angeles, CA: Sage. 
Black, P., \& Wiliam, D. (2009). Developing a theory of formative assessment. Educational Assessment, Evaluation and Accountability, 21, 5-31.

Brookhart, S. M. (2011). Educational assessment knowledge and skills for teachers. Educational Measurement: Issues and Practice, 30(1), 3-12.

Brown, G. T. L. (2004). Teachers' conceptions of assessment: Implications for policy and professional development. Assessment in Education: Principles, Policy \& Practice, 11(3), 301-318.

Brown, G. T. L. (2006). Teachers' conceptions of assessment: Validation of an abridged instrument. Psychological Reports, 99, 166-170. doi: 10.2466/pr0.99.1.166-170

Brown, G. T. L., \& Harris, L. (2009). Unintended consequences of using tests to improve learning: How improvement-oriented resources heighten conceptions of assessment as school accountability. Journal of MultiDisciplinary Evaluation, 6(12), 68-91.

Brown, G. T. L., Lake, R., \& Matters, G. (2011). Queensland teachers' conceptions of assessment: The impact of policy priorities on teacher attitudes. Teaching and Teacher Education, 27, 210-220.

Bruce, C. D., Esmonde, I., Ross, J., Dookie, L., \& Beatty, R. (2010). The effects of sustained classroom-embedded teacher professional learning on teacher efficacy and related student achievement. Teaching and Teacher Education, 26(8), 1598-1608.

Campbell, C., Murphy, J. A., \& Holt, J. K. (2002, October). Psychometric analysis of an assessment literacy instrument: Applicability to pre-service teachers. Paper presented at the annual meeting of the Mid-Western Educational Research Association, Columbus, $\mathrm{OH}$.

Cowan, E. M. (2009). Implementing formative assessment: Student teachers' experiences on placements. Teacher Development, 13(1), 71-84. 
Cowie, B., Cooper, B., \& Ussher, B. (2014). Developing an identity as a teacher-assessor: Three student teacher case studies. Assessment Matters, 7, 64-89.

Earl, L. M. (2012). Assessment as learning: Using classroom assessment to maximize student learning. Thousand Oaks, CA: Corwin Press.

Gambhir, M., Broad, K., Evans, M., \& Gaskell, J. (2008). Charactering initial teacher education in Canada: Themes and issues. Toronto: University of Toronto, Ontario Institute for Studies in Education. Retrieved on March 27, 2017 from https://www.oise.utoronto.ca/ite/UserFiles/File/ CharacterizingITE.pdf

Graham, P. (2005). Classroom-based assessment: Changing knowledge and practice through preservice teacher education. Teaching and Teacher Education, 21, 607-621.

Gotch, C. M., \& French, B. F. (2014). A systematic review of assessment literacy measures. Educational Measurement: Issues and Practice, 33, 14-18.

Harrison, C. (2010). Peer and self-assessment. In P. Peterson, E. Baker \& B. McGaw (Eds.), International encyclopedia of education (3rd ed.), (pp. 231-235). Oxford, UK: Academic Press.

Heritage, M., \& Heritage, J. (2013). Teacher questioning: The epicenter of instruction and assessment. Applied Measurement in Education, 26(3), 176-190.

Herman, J. L. (2008). Accountability and assessment: Is public interest in K-12 education being served? In K. E. Ryan \& L. A. Shepard (Eds.), The future of test-based educational accountability (pp. 211-231). New York: NY: Routledge.

Hoover, N. R., \& Abrams, L. M. (2013). Teachers' instructional use of summative student assessment data. Applied Measurement in Education, 26(3), 219-231. 
Joint Committee for Standards on Educational Evaluation. (2015). Classroom assessment standards: Practices for PK-12 teachers. Retrieved on March 27, 2017 from http://www.jcsee.org/theclassroom-assessment-standards-new-standards

Kauffman, D., Johnson, S. M., Kardos, S. M., Liu, E., Peske, H. G. (2002). "Lost at sea": New teachers' experiences with curriculum and assessment. Teachers College Record, 104(2), 273300.

Klenowski, V. (2010). Portfolio assessment. In P. Peterson, E. Baker \& B. McGaw (Eds.), International encyclopedia of education (3rd ed.), (pp. 236-242). Oxford, UK: Academic Press.

Looney, A., Cumming, J., van Der Kleij, F., \& Harris, K. (2017). Reconceptualising the role of teachers as assessors: teacher assessment identity. Assessment in Education: Principles, Policy \& Practice, 1-26. doi: 10.1080/0969594X.2016.1268090

MacLellan, E. (2004). Initial knowledge states about assessment: Novice teachers' conceptualizations. Teaching and Teacher Education, 20, 523-535.

Mertler, C. A. (2003, October). Pre-service versus inservice teachers' assessment literacy: Does classroom experience make a difference? Paper presented at the Annual Meeting of the MidWestern Educational Research Association, Columbus, $\mathrm{OH}$.

Mertler, C. A. (2004). Secondary teachers' assessment literacy: Does classroom experience make a difference?. American Secondary Education, 33(1), 49-64.

Mertler, C.A., \& Campbell, C. (2005). Measuring teachers' knowledge \& application of classroom assessment concepts: Development of the assessment literacy inventory. In Annual meeting of the American Educational Research Association, Montreal. 
Newmann, F. M., Secada, W. G., \& Wehlage, G. (1995). A guide to authentic instruction and assessment: Vision, standards and scoring. Madison: Wisconsin Center for Education Research.

Nichols, S. L., \& Harris, L. R. (2016). Accountability assessment's effect on teachers and schools In G. T. L. Brown \& L. R. Harris (Eds), Handbook of Human and Social Conditions in Assessment (pp. 4-56).

O’Sullivan, R. S., \& Johnson, R. L. (1993, April). Using performance assessments to measure teachers' competence in classroom assessment. Paper presented at the annual meeting of the American Educational Research Association, Atlanta, GA.

Plake, B., Impara, J., \& Fager, J. (1993). Assessment competencies of teachers: a national survey. Educational Measurement: Issues and Practice, 12(4), 10-39. doi:10.1111/j.17453992.1993.tb00548.x.

Popham, W. J. (2009). Assessment literacy for teachers: Faddish or fundamental? Theory into Practice, 48(1), 4-11.

Popham, W. J. (2013). Classroom assessment: What teachers need to know (7th ed.). Boston, MA: Pearson.

Remesal, A. (2011). Primary and secondary teachers' conceptions of assessment: A qualitative study. Teaching and Teacher Education, 27, 472-482.

Ruiz-Primo, M. A., \& Li, M. (2013). Analyzing teachers' feedback practices in response to students' work in science classrooms. Applied Measurement in Education, 26(3), 163-175.

Salend, S. J. (2009). Technology-based classroom assessments. Teaching Exceptional Children, $41(6), 48-58$. 
Scarino, A. (2013). Language assessment literacy as self-awareness: Understanding the role of interpretation in assessment and in teacher learning. Language Testing, 30(3), 309-327.

Shepard, L. A. (2000). The role of assessment in a learning culture. Educational Researcher, 29(7), 4-14.

Smith, L. F., Hill, M. F., Cowie, B., \& Gilmore, A. (2014). Preparing teachers to use the enabling power of assessment. In C. Wyatt-Smith, V. Klenowski \& P. Colbert (Eds.). Designing assessment for quality learning (pp. 303-323). Heidelberg, NE: Springer.

Stiggins, R. J. (1991). Assessment literacy. Phi Delta Kappan, 72(7), 534-539.

Stiggins, R. (2005). From formative assessment to assessment for learning: A path to success in standards-based schools. The Phi Delta Kappan, 87(4), 324-328.

Stobart, G. (2008). Testing times: The uses and abuses of assessment. New York, NY: Routledge. Taras, M. (2007). Assessment for learning: Understanding theory to improve practice. Journal of Further and Higher Education, 31(4), 363-371.

Tierney, R. D. (2006). Changing practices: Influences on classroom assessment. Assessment in Education, 13(3), 239-264.

Volante, L., \& Fazio, X. (2007). Exploring teacher candidates' assessment literacy: Implications for teacher education reform and professional development. Canadian Journal of Education, $30(3), 749-770$.

Webb, N. L. (1997). Criteria for alignment of expectations and assessments in mathematics and science education. Washington, DC: Council of Chief State School Officers.

Webb, N. L. (1999). Alignment of science and mathematics standards and assessments in four states. Washington, DC: Council of Chief State School Officers. 
Webb, N. L. (2005). Webb alignment tool: Training manual. Madison: Wisconsin Center for Education Research. Retrieved on March 27, 2017 from http://www.wcer.wisc.edu/WAT/index.aspx

Wen, M. L., Tsai, C., Chang, C. (2006). Attitudes towards peer assessment: A comparison of the perspective of pre-service and in-service teachers. Innovation in Education and Teaching International 43(1), 83-92.

Willis, J., Adie, L., \& Klenowski, V. (2013). Conceptualizing teachers' assessment literacies in an era of curriculum and assessment reform. The Australian Educational Researcher, 40(2), 241256.

Wolf, D., Bixby, J., Glenn III, J., \& Gardner, H. (1991). To use their minds well: Investigating new forms of student assessment. Review of Research in Education, 17, 31-74.

Xu, Y., \& Brown, G. T. (2016). Teacher assessment literacy in practice: A reconceptualization. Teaching and Teacher Education, 58, 149-162.

Zhang, Z., \& Burry-Stock, J. A. (2003). Classroom assessment practices and teachers' self-perceived assessment skills. Measurement in Education, 16(4), 323-342. 
Tables

Table 1

Demographics for all participants $(n=727)$.

\begin{tabular}{|c|c|c|c|c|c|c|}
\hline Demographic & & $\begin{array}{c}\text { Frequency } \\
(\%)\end{array}$ & $\begin{array}{c}\text { Initial } \\
\text { Pre- } \\
\text { Service } \\
\text { Teacher } \\
(\%) \\
\end{array}$ & $\begin{array}{c}\text { Beginnin } \\
\text { g In- } \\
\text { Service } \\
\text { Teacher } \\
(\%)\end{array}$ & $\begin{array}{c}\text { Early In- } \\
\text { Service } \\
\text { Teacher } \\
(\%)\end{array}$ & $\begin{array}{c}\text { Establishe } \\
\text { d In- } \\
\text { Service } \\
\text { Teacher } \\
(\%)\end{array}$ \\
\hline \multirow{2}{*}{ Gender } & Female & 83.1 & 88.5 & 80.2 & 81.8 & 81.1 \\
\hline & Male & 16.9 & 11.5 & 19.8 & 18.2 & 18.9 \\
\hline \multirow{3}{*}{ Age } & $20-25$ & 35.0 & 89.8 & 75.6 & 14.7 & 0.0 \\
\hline & $26-35$ & 35.0 & 7.0 & 18.0 & 70.6 & 25.8 \\
\hline & 36 or over & 30.0 & 3.2 & 6.4 & 14.7 & 74.2 \\
\hline \multirow{4}{*}{$\begin{array}{l}\text { Assessment } \\
\text { Education }\end{array}$} & Full-year course & 7.1 & 0.0 & 11.6 & 13.8 & 15.2 \\
\hline & Half-year course & 18.8 & 0.0 & 38.7 & 40.5 & 28.0 \\
\hline & Module & 15.0 & 0.0 & 43.3 & 22.4 & 15.2 \\
\hline & No formal training & 59.1 & 100.0 & 6.4 & 23.3 & 41.7 \\
\hline
\end{tabular}




\section{Table 2}

Assessment literacy themes and associated priority descriptions

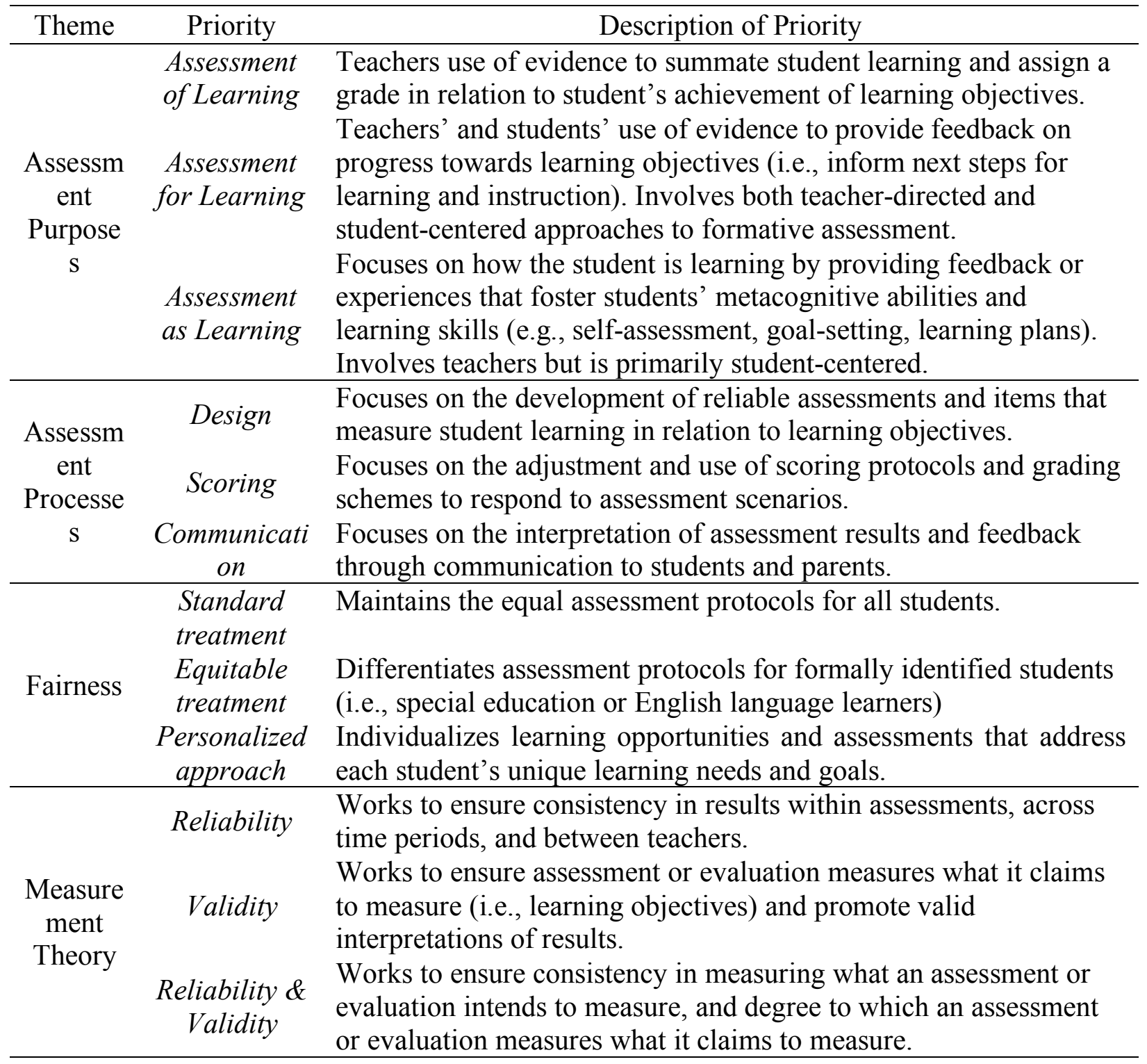

Table 3

Survey Blueprint for Scenario 1

\begin{tabular}{|c|c|c|}
\hline Theme & Priority & Response Options \\
\hline $\begin{array}{c}\text { Assessm } \\
\text { ent }\end{array}$ & $\begin{array}{l}\text { Assessment } \\
\text { of Learning }\end{array}$ & $\begin{array}{l}\text { Record the test grade as each student's summative assessment for } \\
\text { the unit but reduce its weight in the final grade. }\end{array}$ \\
\hline $\begin{array}{l}\text { Purpose } \\
\text { S }\end{array}$ & $\begin{array}{l}\text { Assessment } \\
\text { for Learning }\end{array}$ & $\begin{array}{l}\text { Based on your analysis of the test, re-teach parts of the unit } \\
\text { focusing on items students struggled with, give students }\end{array}$ \\
\hline
\end{tabular}




\begin{tabular}{|c|c|c|}
\hline & $\begin{array}{l}\text { Assessment } \\
\text { as Learning }\end{array}$ & $\begin{array}{l}\text { opportunities to apply their learning, and then re-test material. } \\
\text { Ask students to reflect on their test preparation, analyze their test } \\
\text { responses, and make a personal plan for re-learning the material. } \\
\text { Then re-test the material. }\end{array}$ \\
\hline Assessm & Design & $\begin{array}{l}\text { Recognize that your test design may be flawed and design a revised } \\
\text { unit test to give students. }\end{array}$ \\
\hline $\begin{array}{c}\text { ent } \\
\text { Processe }\end{array}$ & Scoring & $\begin{array}{l}\text { Remove test questions that most students failed and re-calculate } \\
\text { student scores without those questions. }\end{array}$ \\
\hline $\mathrm{s}$ & $\begin{array}{l}\text { Communicati } \\
\text { on }\end{array}$ & $\begin{array}{l}\text { Schedule student conferences (individual or group) to discuss } \\
\text { grades, areas of confusion, and next steps. }\end{array}$ \\
\hline Fairness & $\begin{array}{l}\text { Standard } \\
\text { treatment } \\
\text { Equitable } \\
\text { treatment } \\
\text { Personalized } \\
\text { approach } \\
\end{array}$ & $\begin{array}{l}\text { Allow all students to retake a similar test and average the two } \\
\text { grades. } \\
\text { Ensure students with identified learning exceptionalities retake a } \\
\text { similar test and take the better of the two grades for those students. } \\
\text { Have each student who failed the test negotiate with you a new } \\
\text { task/activity that would appropriately demonstrate their learning. }\end{array}$ \\
\hline $\begin{array}{l}\text { Measure } \\
\text { ment } \\
\text { Theory }\end{array}$ & $\begin{array}{l}\text { Reliability \& } \\
\text { Validity }\end{array}$ & $\begin{array}{l}\text { Analyze test questions that the majority of students consistently } \\
\text { answered incorrectly. Then provide students with new questions to } \\
\text { test those concepts. } \\
\text { Consider student test scores in light of previous, formative } \\
\text { assessment information available for each student. Consider this } \\
\text { information and adjust grades accordingly. } \\
\text { Reflect on which students failed, considering wording of test items } \\
\text { and extenuating circumstances that may have contributed to the } \\
\text { failure in relation to previous assessment information. Then adjust } \\
\text { grades accordingly. }\end{array}$ \\
\hline
\end{tabular}

\section{Table 4}

Descriptive Statistics (mode) of Approaches for All Participants $(N=727)$ by Career Stage

\begin{tabular}{|c|c|c|c|c|c|c|c|}
\hline Theme & Priority & & $\begin{array}{l}\text { Frequen } \\
\text { cy }(\%)\end{array}$ & $\begin{array}{c}\text { Initial } \\
\text { Pre- } \\
\text { Service } \\
\text { Teacher } \\
(\%)\end{array}$ & $\begin{array}{c}\text { Beginni } \\
\text { ng In- } \\
\text { Service } \\
\text { Teacher } \\
(\%)\end{array}$ & $\begin{array}{c}\text { Early } \\
\text { In- } \\
\text { Service } \\
\text { Teacher } \\
(\%)\end{array}$ & $\begin{array}{c}\text { Establis } \\
\text { hed In- } \\
\text { Service } \\
\text { Teacher } \\
(\%)\end{array}$ \\
\hline Assessment & & AoL & 6.1 & $3.0_{\mathrm{a}}$ & $6.9_{\mathrm{a}, \mathrm{b}}$ & $\begin{array}{r}10.2 \\
b\end{array}$ & $4.7 \mathrm{a}, \mathrm{b}$ \\
\hline Purposes & & $A f L$ & $\begin{array}{r}44 . \\
8\end{array}$ & $\begin{array}{r}41.9 \\
\mathrm{a}\end{array}$ & $40.5 \mathrm{a}$ & $\begin{array}{r}44.0 \\
\mathrm{a}\end{array}$ & $52.6 \mathrm{a}$ \\
\hline
\end{tabular}




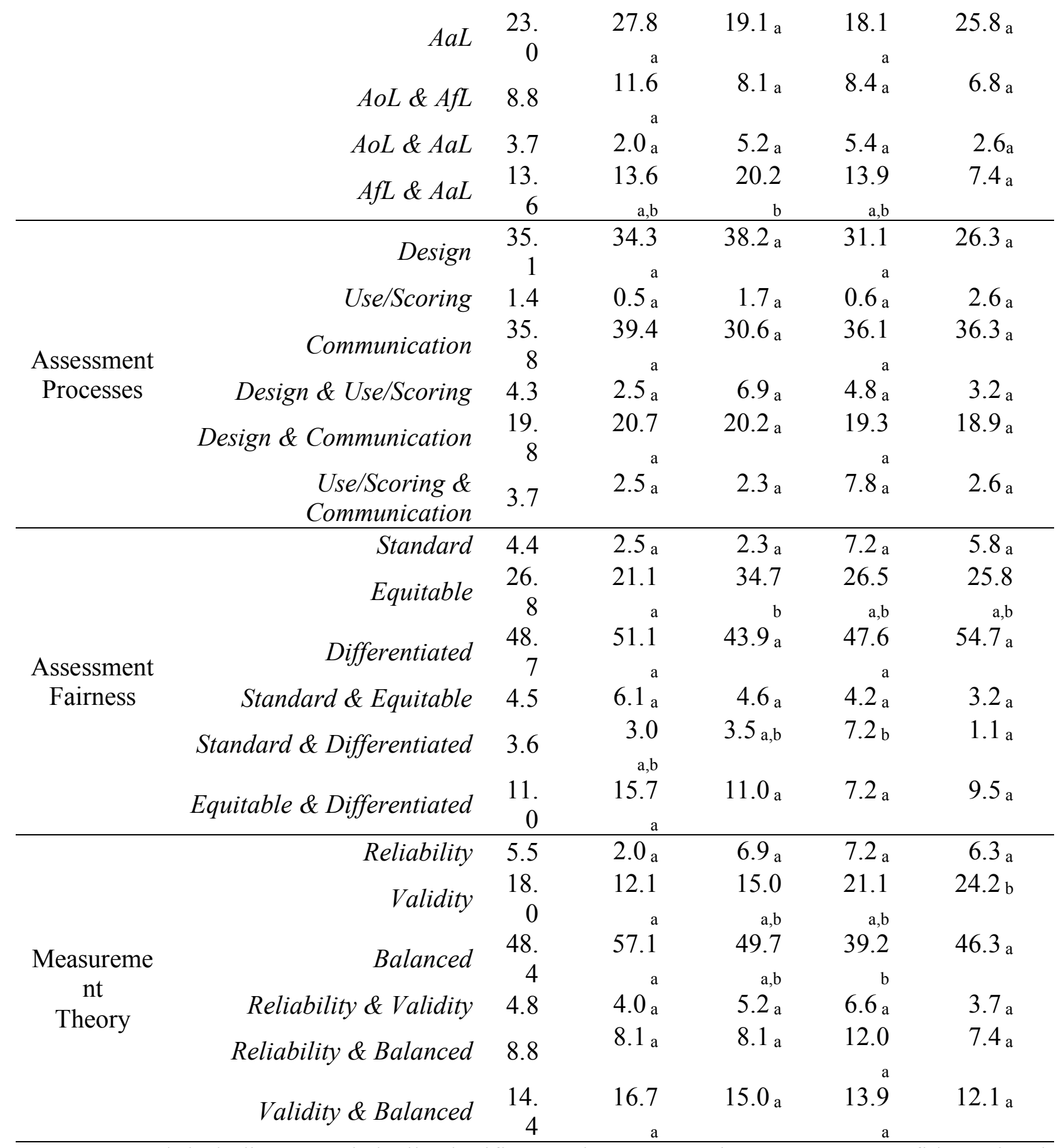

Note. 'a' and 'b' indicates statistically significant column proportions at $\mathrm{p}<.05$ confidence level.

Table 5

Most Common Assessment Profiles for Initial Pre-Service Teachers (113 profiles with 198 participants), Beginning In-Service Teachers (111 profiles with 173 participants), Early InService Teachers (112 profiles with 166 participants), and Established In-Service Teachers Profiles (107 profiles with 190 participants). 


\begin{tabular}{|c|c|c|c|c|c|}
\hline Profile ID & $\begin{array}{c}\text { Frequenc } \\
\text { y (\%) }\end{array}$ & Purpose & Process & Fairness & $\begin{array}{c}\text { Measuremen } \\
t\end{array}$ \\
\hline \multirow{5}{*}{$\begin{array}{l}\text { Initial Pre- } \\
\text { Service } \\
\text { Teachers }\end{array}$} & 6.6 & $A a L$ & $\begin{array}{c}\text { Communicati } \\
\text { on }\end{array}$ & Differentiated & Balanced \\
\hline & 4.0 & $A f L$ & Design & Equitable & Balanced \\
\hline & 4.0 & $A f L$ & $\begin{array}{c}\text { Communicati } \\
\text { on }\end{array}$ & Differentiated & Balanced \\
\hline & 4.0 & $A a L$ & Design & Differentiated & Balanced \\
\hline & 3.5 & $A f L$ & $\begin{array}{c}\text { Communicati } \\
\text { on }\end{array}$ & Differentiated & Balanced \\
\hline \multirow{5}{*}{$\begin{array}{l}\text { Beginning In- } \\
\text { Service } \\
\text { Teachers }\end{array}$} & 3.5 & $A f L$ & Design & Differentiated & Balanced \\
\hline & 2.5 & AfL & Design & Equitable & Balanced \\
\hline & 2.5 & $A f L$ & $\begin{array}{c}\text { Design \& } \\
\text { Comm. }\end{array}$ & Differentiated & Balanced \\
\hline & 2.5 & $A a L$ & Design & Differentiated & Balanced \\
\hline & 2.5 & $A a L$ & $\begin{array}{c}\text { Communicati } \\
\text { on }\end{array}$ & Differentiated & Balanced \\
\hline \multirow{5}{*}{$\begin{array}{l}\text { Early In- } \\
\text { Service } \\
\text { Teachers }\end{array}$} & 4.0 & $A a L$ & $\begin{array}{c}\text { Communicati } \\
\text { on }\end{array}$ & Differentiated & Balanced \\
\hline & 2.5 & $A f L$ & Design & Differentiated & Balanced \\
\hline & 2.5 & $A f L$ & $\begin{array}{c}\text { Communicati } \\
\text { on }\end{array}$ & Differentiated & Balanced \\
\hline & 2.0 & $A f L$ & $\begin{array}{c}\text { Communicati } \\
\text { on }\end{array}$ & Differentiated & Validity \\
\hline & 2.0 & $A f L$ & $\begin{array}{l}\text { Design \& } \\
\text { Comm. }\end{array}$ & Differentiated & Balanced \\
\hline \multirow{4}{*}{$\begin{array}{l}\text { Established In- } \\
\text { Service } \\
\text { Teachers }\end{array}$} & 5.1 & AfL & $\begin{array}{c}\text { Communicati } \\
\text { on }\end{array}$ & Differentiated & Balanced \\
\hline & $\begin{array}{l}4.0 \\
3.5\end{array}$ & $\begin{array}{l}\text { AaL } \\
\text { AfL }\end{array}$ & $\begin{array}{l}\text { Design } \\
\text { Design }\end{array}$ & $\begin{array}{l}\text { Differentiated } \\
\text { Equitable }\end{array}$ & $\begin{array}{l}\text { Balanced } \\
\text { Balanced }\end{array}$ \\
\hline & 3.5 & $A a L$ & $\begin{array}{c}\text { Communicati } \\
\text { on }\end{array}$ & Differentiated & Balanced \\
\hline & 3.0 & AfL & $\begin{array}{c}\text { Communicati } \\
\text { on }\end{array}$ & Differentiated & Balanced \\
\hline
\end{tabular}

Note. AaL $=$ Assessment as Learning, $A f L=$ Assessment for Learning, Comm. $=$ Communication. 